\title{
Aproximando-se da Distância: as principais disparidades do Pensamento Fraco de Vattimo ante a Ontologia heideggeriana
}

Approaching the Distance: The Major Disparities of
Vattimo's Weak Thought with the Heideggerian Ontology

Dndo. Gabriel Debatin gabrieldebatin@gmail.com Universidade Federal de Santa Catarina

O presente ensaio pretende apresentar uma série de distanciamentos fundamentais entre o pensamento do italiano Gianni Vattimo, centrado no conceito de pensamento fraco, com a ontologia heideggeriana. A problemática consiste no confesso fato de Vattimo basear seu pensamento na filosofia de Heidegger; contudo, sob forte influência do pensamento de Nietzsche, o filósofo italiano acaba por desvirtuar certos conceitos cruciais da filosofia heideggeriana, conduzindo-a a conclusões diametralmente opostas às suas. Vattimo assevera, assim, que há um elemento niilista que perpassa toda a ontologia heideggeriana, não, contudo, apenas como um sintoma de uma sociedade decadente e indefinida, mas julga esta mesma ausência de sentido como a própria superação da metafísica tão almejada pela filosofia da história de Heidegger.

\section{PALAVRAS-CHAVE}

Fundamento. Técnica. Niilismo. An-denken.

Vattimo. Heidegger

The following essay aims to introduce a series of fundamental detachments between the Italian thinker Gianni Vattimo, focused in the concept of weak thought, and the Heideggerian ontology. The main issue consists in the admitted fact by Vattimo that he supports his thought in the philosophy of Martin Heidegger; however, under strong influence of the Nietzschean thought, the Italian philosopher turns out to distort concepts which are critical to the Heideggerian philosophy, leading it to conclusions diametrically opposed to its owns. Therefore, Vattimo sustains that there is a nihilistic element that permeates the entire Heideggerian ontology, not, however, as a mere symptom of a decadent and undefined society, but he believes that this absence of meaning is itself the metaphysical overcome so desired by Heidegger's philosophy of History. 


\section{Introdução}

Segundo o filósofo e político italiano Gianni Vattimo, a Pós-Modernidade é marcada por uma profunda fragmentação dos saberes, a qual não permite a postulação de um saber unitário que seja o fundamento de todos os demais, reunindo-os sob um mesmo e unívoco arcabouço teórico. Tal ruptura, que da filosofia subtrai o clássico posto de ciência primeira, caracteriza-se pela impossibilidade de conferir aos sempre muitos posicionamentos teóricos - quer de ordem filosófica, quer científica - o status de verdade, de modo que perspectiva alguma pode se afirmar como definitiva e conclusiva, o que, conforme o mesmo pensador, é típico das posturas marcadamente metafísicas. Tais posturas, com o advento do período pós-moderno, podem enfim se ver superadas. Precisamente pela perda de força que acomete o pensamento na Pós-Modernidade, Vattimo chama seu principal conceito de pensiero debole, pensamento fraco, o qual procura servir como análise do atual momento histórico, em que, devido à perda de referencial estável para o pensamento, dá-se cada vez mais uma democratização filosófica consonante à abertura e liberdade interpretativa.

De acordo com o pensador fraco, a condição pós-moderna remete, em sua origem, a uma determinação ontológica, a qual não compreende o ser como fundamento último da realidade, mas como uma abertura histórica, da qual resulta a liberdade de não ser metafisicamente fundado. Tal ontologia, todavia, não pode apresentar-se senão fracamente, ou seja, sem postular-se como um pretenso posicionamento mais verdadeiro, não habilitando nem mesmo a noção de ser como um ponto de referência inabalável, forte, para o pensamento, perfazendo, portanto, uma ontologia do declínio que é, inevitavelmente, também um declínio da ontologia (Cf. VATTIMO, 1998, p. 37-38).

Quem teria prefigurado essa condição fraca, inaugurando o período pós-moderno, segundo Vattimo, foi Nietzsche, com seu anúncio niilista do fim do pensamento metafisicamente fundado, seguido por Heidegger, que pensa o ser não como presença, mas como um evento que se dá na história, ao qual cabe, conforme a interpretação do pensador italiano, uma soturna tematização de pano de fundo, apenas rememorá-lo ao invés de presentificá-lo. Não obstante, do ponto de vista conceitual, pensiero debole se dispõe como uma série de alusões a conceitos de Nietzsche e Heidegger, traçando um caminho ao interno de suas filosofias. Suas não poucas alusões a eles, contudo, são revestidas de uma interpretação sui generis, que os insere em seu projeto niilista de rechaço à metafísica e de liberdade hermenêutica. Dessarte, o filósofo italiano propõe uma abertura interpretativa a Nietzsche e a Heidegger, intento que, entretanto, não necessariamente se adequa em plenitude aos projetos teóricos originais de ambos os filósofos alemães. 
Aí se encontra o locus do presente ensaio: enquanto o projeto hermenêutico de Vattimo aparenta, em linhas gerais, alinhar-se ao nexo niilista da filosofia de Nietzsche, suas alusões a Heidegger parecem forçar a ontologia deste a percorrer um caminho demasiadamente distinto de seu propósito original. Dessa forma, atendo-se às alusões de Vattimo ao pensamento de Heidegger, este ensaio procurará sucintamente contrapor a interpretação que o pensador fraco faz da ontologia heideggeriana em relação a Heidegger mesmo, ou, o que seria equivalente, a uma interpretação mais tradicional e ortodoxa de sua filosofia. Vale ressaltar que, com isso, não se pretende avaliar se Vattimo foi ou não um bom leitor e intérprete de Heidegger, dado que o pensador italiano não é um simples comentador de sua filosofia, mas sem dúvida se trata de um autêntico filósofo dos nossos tempos. Não faria sentido, portanto, questionar uma suposta "correção interpretativa" de sua parte, mas sim pôr em evidência a tensão que sua leitura do pensamento heideggeriano efetua em relação a interpretações mais textuais da filosofia de Heidegger.

\section{O problema do fundamento (Grund)}

Conceitualmente, a distância existente entre ambos os filósofos se pode começar a verificar no tocante a suas aproximações da tradição metafísica. Em Vattimo se constata um rechaço aos traços metafísicos do pensamento, ao empoderamento da razão, que, segundo ele, a partir de um apelo ao ser como fundamento do mundo, é capaz de violentar interpretações divergentes, enrijecendo o pensamento em sua "couraça metafísica". Nas palavras do italiano,

La ragione deve, al proprio interno, depotenziarsi, cedere terreno, non aver timore di indietreggiare verso la supposta zona d'ombra, non restare paralizzata dalla perdita del riferimento luminoso, unico e stabile, cartesiano [...], dei tratti metafisici del pensiero, prima fra tutti la "forza" che esse ha sempre creduto di doversi attribuire in nome del suo accesso privilegiato all'essere come fondamento (VATTIMO; ROVATTI, 2011, p. 10; Cf. também ANTISERI, 1995, p. 9-10). ${ }^{1}$

1 A razão deve, ao próprio interno, despotencializar-se, ceder terreno, não ter medo de retroceder a uma suposta zona de sombras, não ficar paralisada pela perda do referencial luminoso, estável, cartesiano [...] dos traços metafísicos do pensamento, antes de tudo da "força" que 
Essa rejeição pela metafísica, nos termos postos por Vattimo, remete à consideração de Heidegger acerca da tradição do pensamento ocidental, mais especialmente em relação ao conceito de Grund, fundamento. De acordo com ele, "a metafísica é o pensamento que corresponde a uma época do ser em que o ser se dá ao homem no horizonte do Grund, do fundamento ou, com o termo originário grego, do $\lambda o ́ \gamma o \varsigma "$ (VATTIMO, 1988, p. 48). Diante da necessidade de libertar o pensamento, apenas um abandono da noção de fundamento aparentaria gozar da radicalidade requerida para tal. Sua leitura de Heidegger, desse modo, caracteriza-se por ver uma despedida do fundamento efetuado por sua ontologia, em diametral oposição, portanto, à tradição metafísica. Não obstante, Vattimo menciona diversas vezes um trecho da conferência tardia de Heidegger intitulada Tempo e Ser, de 1962, em que o filósofo alemão afirma ser necessário "abandonar o ser como fundamento" (HEIDEGGER, 1996, p. 254; Cf. também VATTIMO, 1998, p. 183).

Todavia, abordando-se mais de perto a caracterização que Heidegger efetua do conceito de fundamento em O princípio do fundamento, de 1956, pode-se perceber que sua consideração a respeito não se resume em um rechaço pleno, tal como constatado em Vattimo. O pensador alemão principia por interpelar o conceito a partir de sua formulação no clássico principium rattionis sufficientis, princípio de razão suficiente, articulado por Leibniz mas remetendo diretamente à metafísica aristotélica. O principium prega que nenhum ente é sem fundamento, sem uma razão de ser.

Escreve Leibniz no tratado Prima Veritates:

Semper igitur prædicatum seu consequens inest subjecto seu antecedenti. Et in hoc ipso consistit natura veritatis in universum seu connexio inter terminos enuntiationis, ut etiam Aristoteles observavit. Et in identicis quidem connexio illa atque comprehensio prædicati in subjacto est expressa, in reliquis omnibus implicita, ac per analysin notionum ostendenda, in qua demonstratio a priori sita est. [...] Ex his propter nimiam facilitatem suam non satis consideratis multa consequuntur magni momenti. Statim enim hinc nascitur axioma receptum nihil esse sine ratione, seu nullum effectum esse absque causa. Alioqui veritas daretur, quæ non posset proba-

ele sempre acreditou que se deveria atribuir em nome de seu acesso privilegiado ao ser como fundamento. [Tradução nossa]. 
ri a priori, seu quæ non resolveretur in identicas, quod est contra naturam veritatis, quæ semper vel expresse vel implicite identica est (LEIBNIZ, In: COUTURAT, 1903, p. 518-519). ${ }^{2}$

Para além da pressuposição de sinonímia entre fundamento e causa, é claro no texto de Leibniz citado o intento de demonstrar o nascimento do principium rationis sufficientis a partir da natura veritatis - natureza da verdade -, estabelecendo assim um vínculo entre fundamento e verdade. "Fundamento", aqui, é entendido no sentido de possuir o ente uma razão de ser - daí a correlação entre fundamento, razão e causa. Leibniz defende, com efeito, que se o principium não fosse infalível, poderia haver entes possuidores de algo verdadeiro mesmo não sendo necessariamente fundados, o que coincide em dizer que tais supostos entes não fundados, embora sendo verdadeiros, resistiriam a uma redução a identidades. Acarretaria, por exemplo, na possibilidade lógica de proposições do tipo "A é diferente de A". Heidegger apõe à caracterização leibniziana da identidade o fato de que "qualquer coisa é o mesmo e nada mais que o mesmo: o mesmo ele mesmo, o mesmo consigo-mesmo" (HEIDEGGER, 1999, p. 19). Contudo, em um contexto relativo à verdade em que se faz mister considerar uma pluralidade de entes correlacionáveis entre si, tal definição de identidade não se apresenta satisfatória, posto que "o mesmo consigo-mesmo" só pode ser, a cada vez, uma unidade determinada. Poder-se-ia definir a identidade na pluralidade de entes como a "união originária do que se encontra em mútua pertença", o que coincide, embora seguindo a via inversa, com a "co-pertença de vários com o fundamento do mesmo" (Ibid., loc. cit), de modo que a natureza da verdade, no entendimento de Leibniz, consiste na concordância do juízo com a identidade do ente, firmando-se, enfim, a proposição como âmbito próprio do dar-se da verdade.

Para Heidegger, contudo, a um fenômeno mais originário da verdade remonta aquela que se dá na proposição, de modo que tal acontecimento se dá pré- e não-predicativamente. $\mathrm{O}$ desvelamento - Unverborgenheit, às vezes também

\footnotetext{
2 Sempre, portanto, um predicado ou consequência está contido no sujeito ou em antecedentes. E nisso mesmo é que consiste a natureza da verdade no universo ou a conexão entre os termos da enunciação, como Aristóteles também observou. E nos entes idênticos, de fato, tal conexão e compreensão do predicado no sujeito está expressa, enquanto em todas as outras coisas está implícita, o que se deve demonstrar pela análise das noções, na qual está situada a demonstração a priori. [...] Por causa destas coisas, não consideradas o bastante devido sua demasiada facilidade, seguir-se-ão grandes momentos. Logo, daqui, pois, nasce o axioma recebido, nada é sem razão, ou nulo é o efeito sem causa. Se de outro modo a verdade se desse, não se poderia prová-la a priori, ou ela não se resolveria na identidade, o que é contra a natureza da verdade, que quer expressa, quer implícita, é sempre idêntica. [Tradução nossa].
} 
traduzido por desocultamento - do ente - $\dot{\alpha} \lambda \eta \dot{\theta} \theta \varepsilon \imath \alpha$, no original grego - acontece em um âmbito veritativo anterior à verdade proposicional, de modo que a verdade ôntica, relativa ao ente, se estabelece como pré-apofântica. Remontando-se ao parágrafo 44 de Ser e Tempo, de 1927, o filósofo da Floresta Negra propõe uma distinta tradução de $\dot{\alpha} \lambda \dot{\eta} \theta \varepsilon ı \alpha$, que a tradição costuma traduzir por verdade. Preferindo sua tradução do grego como desvelamento, Heidegger passa a referir-se a um acontecimento mais originário do que a verdade concebida pela tra-

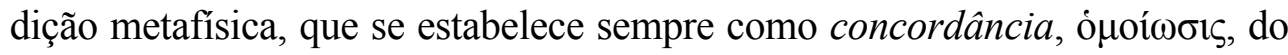
intelecto ao ente e, por decorrência, assume a proposição como seu lugar mais próprio. $\mathrm{O}$ acontecimento originário da verdade - que é ainda anterior à verdade ôntica -, que remete a um acontecimento do ser, teria se avizinhado ao pensamento dos gregos antigos, embora eles não tivessem conseguido expressá-lo em termos de desvelamento, declinando o sentido de $\dot{\alpha} \lambda \hat{\eta} \theta \varepsilon \iota \alpha$ como "retitude da percepção", evidência, concordância. Contudo, tal âmbito veritativo é apenas derivado do desvelamento do ente - que ainda se difere do desvelamento do ser -, de uma verdade mais original em relação à verdade da proposição, ao $\lambda$ -se à coisa mesma, e, portanto, é pré-predicativa (Cf. HEIDEGGER, 2012a, p. 609ss; Cf. também Id., 2008, p. 215-150; Cf. ainda SEVERINO, 1994, p. 284-286; e DAHLSTROOM, In: CROWELL; MALPAS (Org.), 2007, p. 63). ${ }^{3}$

Heidegger, contudo, em momento algum de sua obra invalida o enunciado do principium e, consequentemente, o fundamento metafísico, mas o insere num dos grandes marcos de sua filosofia: a diferença ontológica. Considerando que, para o filósofo alemão, a metafísica é a história do pensamento ocidental que pensa, em cada época, o ente, porém sempre e a cada vez mais esquecendo-se do ser, o principium ocupa um legítimo âmbito de verdade ôntica, do ente, mas não versa sobre o desvelamento do ser. Isso não quer dizer que o fundamento seja improcedente; pelo contrário, o fundamento de fato funda. Entretanto, trata-se do modo metafísico de versar sobre a verdade do ente, e não do ser. Heidegger, então, procura pensar a questão do fundamento ao inseri-lo mais originariamente

3 "O que antes foi exposto sobre o termo $\lambda$ ó $\gamma$ os e $\dot{\alpha} \lambda \eta \dot{\eta} \theta \varepsilon 1 \alpha$, numa interpretação como que dogmática, recebeu agora sua comprovação fenomênica. A "definição" de verdade proposta não se livra da tradição, mas dela se apropria originariamente: e o faz tão mais claramente, se consegue demonstrar que e como a teoria devia chegar à ideia da concordância, por ter sua fundação no fenômeno originário da verdade" (HEIDEGGER, 2012a, p. 609). [Grifo do autor]. "O fenômeno existenciário do ser-descoberto (verdade), fundado na abertura do Dasein, torna-se propriedade subsistente, ainda abrigando em si um caráter-de-relação que como tal se desfaz, numa relação subsistente. A verdade como abertura e como ser-descobridor do ente descoberto se torna verdade como concordância entre subsistentes no interior-do-mundo [intelectus e res]. Foi mostrado, assim, o caráter ontologicamente derivado do conceito tradicional de verdade" (Ibid., p. 621-623). [Grifo do autor]. 
no âmbito da verdade ontológica, impensada pela metafísica (Cf. BLANC, 1984, p. 66). Tanto é assim que se lê, em A essência do fundamento, de 1929, que "pelo fato de o "fundamento" ser um caráter transcendental essencial do ser em geral, o princípio da razão é válido com relação ao ente" (HEIDEGGER, 1999, p. 185); e também mais uma vez diz claramente: "o pequeno princípio do fundamento: "Nada é sem fundamento" fala antes de tudo como dito do ser e designa este como o fundamento. Mas apenas por isso, porque o dito do ser é verdadeiro, é legítimo também o princípio fundamental do conceber" (Ibid., p. 182).

Ao passo que o ente é fundado, adequando-se ao enunciado no principium, o ser não o é. Não podendo ser Grund, fundamento, só pode ser Ab-grund, sem-fundamento, abismo, relação evidenciada pela analítica existencial do Dasein operada pelo primeiro Heidegger. O Dasein, que se dá em comum-pertença ao ser, também não é fundado, mas, ao contrário, é transcendente, vai para além do fundamento e salta no abismo do ser (Cf. Id., 2008, p. 146). ${ }^{4}$

O dito de Heidegger que Vattimo constantemente cita, o qual afirma ser necessário abandonar o ser como fundamento, entende-se apenas no contexto da preleção Tempo e Ser, em que o filósofo alemão procura pensar o ser ele mesmo, que nada tem de entitativo e que, portanto, não pode ser pensado como fundamento. A asserção, portanto, só faz sentido quando considerada no ínterim metodológico da preleção, e, em absoluto, não quando tomada isoladamente.

Enquanto Heidegger procura remontar a questão do fundamento às origens do pensamento ocidental, num movimento que caracteriza toda a sua filosofia, Vattimo despede-se tanto do fundamento, quanto das origens. Para ele, um pensamento que queira de fato superar a metafísica não pode apresentar de modo algum novos fundamentos, ou retornar a um fundamento mais primordial que possua a intensão de se assumir como mais verdadeiro, o que acabaria por coincidir com a proposta de uma nova metafísica. No retorno às origens de Heidegger, entretanto, não há postulação de nova metafísica: há, pelo contrário, a intenção de ressignificá-la ao continuamente revisitá-la sob a égide da diferença ontológica, pensando-a em sua verdade essencial (Cf. Id., 1999, p.182; Cf. também Id., 1969, p. 37; Id., 1983, p. 8; e ainda CAPUTO, 1970, p. 26).

4 "A abertura do abismo na transcendência fundante é muito antes um movimento primordial, que a liberdade realiza conosco mesmo" (HEIDEGGER, 2008, p. 146). O caráter abissal da liberdade da existência humana se configura na mais extrema de suas possibilidades, dando contorno ao próprio ser-no-mundo: ser-para-a-morte - Sein zum Tode-, o qual, temporalizado, assume sua pertença ao nada: "ser-fundamento de um ser determinado por um não - isto é, ser-fundamento de uma nulidade". Abandonando-se em seu próprio abismo, "o Dasein é ele mesmo uma nulidade de si mesmo" (Id., 2012, p. 777), enquanto aberto ao desvelamento que é a verdade do ser. [Nota do pesquisador]. 


\section{Metafísica, técnica e niilismo}

Tendo-se analisado o princípio da metafísica, o problema do fundamento, pode-se passar ao seu ponto final: a questão da técnica, tal como posta pelo filósofo alemão e interpretada pelo italiano. Ora, se Vattimo pretende ser coerente em sua defesa da Pós-Modernidade, não pode, de modo algum, recusar o domínio técnico, em que consiste o que há de mais próprio do atual período histórico.

Na perspectiva teórica de Vattimo, aqui em consonância com Heidegger, o domínio da técnica (pós)moderna e de sua Ge-stell - im-posição - é a característica fundamental da Pós-Modernidade, refletindo sua influência em todos os cenários da humanidade. A era da técnica, com efeito, caracteriza-se pelo domínio do ente em sua totalidade defrontado como fundo de reserva a ser explorado, transformado e consumido. Se a metafísica, desconsiderando a diferença ontológica, toma apenas o ente em sua perspectiva e não o propriamente ser, abandonando-o, a técnica consuma sua relação ôntica através do domínio total do ente e consequente velamento máximo do ser. Contudo, sendo um momento destinal do ser, há, na essência da técnica moderna, um apelo que clama por ser ouvido (Cf. VATTIMO, 1998, p. 37).

Segundo a filosofia heideggeriana, no curso do destino historial da tradição metafísica, o homem acabou se tornando impedido de pôr-se ante o apelo da verdade originária do ser ele mesmo, não se apresentando para o homem do período que consuma a metafísica, para o homem sob o modo-de-ser da técnica, a compreensão de ser como abismo, legítima quando considerada no âmbito da verdade originário-ontológica em distinção ao fundamento da verdade ôntica. No modo-de-ser da técnica moderna e de sua imposição cada vez menos se tem abertura ao ser, uma vez que apenas na esfera do ente se situa todo o considerar, no sumo grau de velamento ontológico; é a época do niilismo consumado, onde há nada de ser. Se aquilo que há de mais próprio na metafísica é a verdade ôntica tomada em todas as suas derivações como único campo genuíno do pensamento, perspectiva tal advinda da experiência do ser enquanto fundamento, a técnica completa niilisticamente a metafísica, na qualidade de sua parte destinal-historial integrante e final (Cf. PÖGGELER, 2001, p. 133-139).

De acordo com Heidegger, a imposição técnica, em sua empresa de concatenar causal e tendencialmente todos os entes em um nexo previsível de relações, bem como explorar a totalidade do ente como um fundo de reserva sempre disponível ao consumo, acaba por desumanizar o humano, dessituando-o de sua essência (Cf. HEIDEGGER, 2007, p. 376-381; Cf. também CASANOVA, 2006, p. 155). Essa desumanização operada pela técnica, para Vattimo, é, contudo, um mito: a 
experiência pós-moderna, segundo ele, exige que se ouça o apelo advindo da técnica e sua consequente transitividade valorativa, abraçando a incerteza do homem ante a secularização do mundo, a globalização, a midiatificação e estetização da existência, marcos de uma sociedade que poderia, enfim, tornar-se transparente, fraca. Vattimo entende, desse modo, a experiência proporcionada pela técnica como o caminho salvífico para a humanidade em alternativa à metafísica: "Il mito della tecnica disumanizzante, e anche la "realtà" di questo mito nelle società dell'organizzazione totale, sono irrigidimenti metafisici che continuano a leggere la favola come "verità"' (VATTIMO, 1998, p. 38). ${ }^{5}$ E vai mais além:

O apelo a um "regresso" a Parménides, que se faz valer em nome da luta contra o niilismo da técnica, contrapõe ao caminho eventual do ser, que se mostra no Ge-stell, a recuperação pura e simples da estabilidade do ser teorizada pela tradição metafísica; estabilidade que não se dá (mais) em lado nenhum, já que entretanto a própria tradição metafísica caminhou para o Ge-stell ou, por outras palavras, "Deus morreu" (Id., 1988, p. 175).

Não há, portanto, necessidade alguma de uma efetiva superação da técnica para Vattimo. Pelo contrário, efetivamente superar a metafísica seria abraçar suas consequências. Assim como "Deus morreu" por conta do desenvolvimento da Cristandade, a técnica seria um momento de superação da metafísica por ela mesma proporcionado (Cf. Id., 1998, p. 43-44).

Para Heidegger, contudo, o momento técnico da contemporaneidade é uma crescente derrocada do humano, um declínio que o insere cada vez mais na impessoalidade da existência, nos domínios do nada. Todavia, assevera, de acordo com a relação antitética de seus argumentos, que é necessário que haja um crepúsculo total para que se torne possível uma nova aurora; que haja desolação para que irrompa um novo começo; que o nada vigore para que se dê ser, ou ainda, como diz o célebre verso de Hölderlin, que de onde há perigo pode vir a crescer o que nos salva (Cf. HÖLDERLIN, 1995, p. 395; Cf. também HEIDEGGER, 2007, p. 391).

Desse modo, em distinção a Vattimo, Heidegger pensa a época da técnica como chance para um ulterior novo começo, e não como o próprio começo. $\mathrm{O}$

5 O mito da técnica desumanizante, e também a "realidade" deste misto nas sociedades da organização total, são enrijecimentos metafísicos que continuam a ler a fábula como 'verdade'. [Tradução nossa]. 
niilismo, portanto, seria uma espécie de mal necessário para que se supere a metafísica, mas não constitui, como defende o pensador fraco, a própria superação.

Segundo o filósofo alemão, superar a metafísica não é possível ao simplesmente abandoná-la. A fortiori, todas as metafísicas propostas ao longo da história do pensamento ocidental firmaram-se como recusa e reação a metafísicas anteriores. Heidegger, é claro, não pretende estabelecer uma nova metafísica ao rechaçar as anteriores, mas voltar-se àquilo que por ela permaneceu impensado: o sentido do ser e sua verdade. Assevera, com efeito, na conferência $A$ superação da metafísica, de 1936, que "depois da sua superação, a metafísica não desaparece. Retorna transformada e permanece no poder como a diferença ainda vigente entre ser e ente" (Id., 2012a, p. 62). O não desaparecimento da metafísica após sua superação significa precisamente que superá-la não é excluí-la, juntamente com seus atributos e características, como pretende o niilismo vattimiano, mas dar-se conta de que, estando o ser ainda impensado, é necessário ir além. Não se trata, porém, da exclusão da consideração ôntica por ela oferecida. O propósito de uma Verwindung, isto é, de uma superação da metafísica através da aceitação e do aprofundamento, consiste justamente no dar-se conta da metafísica em sua verdade, no desvelamento nela operado.

Esse dar-se conta, entretanto, afirma Heidegger, indica o fato de que ainda não pensamos; que ao longo da tradição ocidental o ser mesmo permaneceu impensado, estando ainda como algo a-se-pensar. Na época do niilismo consumado há um máximo velamento de ser, a impossibilidade de qualquer vislumbre seu. Para Heidegger, esse nada de ser que se acomete à humanidade é um apelo para que o ser seja, enfim, pensado. Para Vattimo, por outro lado, é a própria meta da história do ser, o ponto final de seu destino, no qual não se dá envio algum do ser.

A adesão de Vattimo ao niilismo nietzschiano aparenta, dessa forma, ser inconciliável com o projeto filosófico heideggeriano. Nietzsche, a quem Vattimo é adepto, não só não supera a metafísica, na peculiar interpretação de Heidegger, como é o pensador de seu acabamento, seu ponto auge. Desvalorizando os chamados valores superiores, a metafísica de Nietzsche procura instaurar novos valores conformes à transitividade da vontade de poder, ou seja, conformes à sua determinação geral do todo do ente, característica metafísica por excelência. Desse modo, o niilismo é um enredamento da metafísica em si mesma, nunca uma superação (Cf. Id., 2000a, p. 228-229).

Vattimo, porém, confere também a Heidegger a alcunha de niilista, como se corroborasse em seu intento. Compreendendo que o niilismo é aquele processo 
histórico em que, ao final, resta senão nada do ser, e que o ser em Heidegger não tem relação alguma com aquilo que é tido por ser na tradição metafísica, Vattimo entende que o niilismo é exatamente o pensamento ultrametafísico que o filósofo alemão almeja (Cf. VATTIMO, 1998, p. 126). Essa afirmação, contudo, contraria a própria letra dos textos de Heidegger, em que o filósofo claramente se afirma oposto ao niilismo. De fato, Heidegger propõe uma retomada pela pergunta sobre o ser e seu sentido desde a primeira linha de Ser e Tempo, perpassando todas as suas fases de produção, da juventude à maturidade (Cf. HEIDEGGER., 2012b, p. 33ss). Sendo assim, o tema do ser na ontologia de Heidegger, longe de ser niilista, é seu conteúdo central, o cerne de sua filosofia, e não, como defende Vattimo, uma temática de pano de fundo, secundária, marginal e inaparente. Explicitamente afirma Heidegger na Carta sobre o humanismo, de 1949:

\begin{abstract}
Este equívoco atinge o cúmulo quando se pretende ver na minha filosofia um "nihilismo", na minha filosofia que não se interroga somente, como em toda a filosofia anterior, sobre o ser do ente, mas sobre a verdade do ser. Pelo contrário, a essência do nihilismo tem como característica o ser incapaz de pensar o nihil (HEIDEGGER, 2005, p. 88).
\end{abstract}

Exatamente na contramão de Heidegger, Vattimo sustenta que o niilismo é a única chance da humanidade pós-moderna devido a ser o processo que abandona o ser como fundamento. Mas para o filósofo alemão, niilismo é exatamente o oposto: é o processo que só é capaz de entender ser como um fundamento, nunca saltando em seu abismo, e por conta disso, é o máximo velamento do ser.

Fato é que o uso da filosofia heideggeriana por parte de Vattimo é antagônica em relação a seu projeto niilista. O pensador fraco aparenta tentar constantemente introduzir Heidegger em um matiz do niilismo nietzschiano, filosofia por demais diversa da sua. Até mesmo em relação ao método, Vattimo parece se alinhar mais à genealogia nietzscheana, que almeja desmascarar a tradição ao demonstrar sua inautenticidade em sua origem, a qual se traduz em falsos valores por ela estabelecidos e já não mais necessários. A fenomenologia heideggeriana, por outro lado, pretende superar a tradição ao pensá-la em relação à sua verdade original, não restando presa à sua decadência, ao esquecimento do ser característico do niilismo. 


\section{A rememoração do ser (An-denken)}

O uso de Vattimo do conceito heideggeriano de An-denken, rememoração, segue a mesma linha da interpretação dada por ele à ideia de Verwindung da metafísica, a qual, à diferença do pensamento de Heidegger, não é uma Verwindung do niilismo; é, pelo contrário, tomado pelo pensador italiano em conformidade ao seu posicionamento niilista. An-denken, a rememoração, dessarte, procuraria expressar uma perspectiva ontológica de simplesmente recordar um ser que é ido, um não-mais ser, porque, com o advento do niilismo consumado, do ser como tal não há mais vestígio algum.

Defende, desse modo, que só se pode pensar o ser como sempre ausente, como "ido embora". Segundo o italiano, portanto, o único meio de pensamento do ser possível é a rememoração, An-denken, pensamento que se opõe a metafísica, consumando sua superação, uma vez que a rememoração só pensaria o ser como não presente, como passado (Cf. VATTIMO, 2011, p. 22). Heidegger, contudo, na Carta sobre o humanismo anseia que "no futuro, o homem seja capaz de pensar a verdade do ser” (HEIDEGGER, 2005, p. 42). A rememoração, portanto, ocupa na consideração de Heidegger um lugar outro que o modo final das possibilidades do pensamento.

Pensar a metafísica em sua verdade, segundo ele, é mirá-la do lado de fora de seu projeto ôntico, que sempre esqueceu o ser. Superar a metafísica, desse modo, é rememorar o que por ela foi esquecido. No âmbito da história do ser, esse rememorar não é prender-se ao passado, porém concentrar a lembrança daquilo que foi esquecido, daquilo que antes de tudo e primordialmente cabe pensar: o ser ele mesmo. Superar a metafísica, logo, não pode ser abraçar esse esquecimento, como opera o niilismo, mas relembrar a necessidade de seu pensamento. An-denken, assim, nunca pensa o ser como ido, como interpreta Vattimo, mas muito mais como vindouro. Recorda-se que ele nunca foi propriamente pensado, e por isso deve passar a ser. Nesse sentido se pode entender outra passagem da Carta sobre o humanismo, em que Heidegger garante que "o ser ainda está à espera de que ele mesmo se torne digno de ser pensado pelo homem” (Id, p. 22; Cf. também Id., 1993, p. 54-56).

Fato é que Vattimo procura continuamente "nietzscheanizar" o pensamento heideggeriano, submetendo seus conceitos ao sulco do processo niilista. A interpretação de Heidegger da filosofia de Nietzsche é, em sua essência, rejeitada por Vattimo, pois este almeja enquadrar a filosofia do primeiro nos moldes próprios do segundo, a contra gosto do próprio Heidegger. Vattimo pretende enquadrar até mesmo a rememoração heideggeriana do ser no âmbito da filosofia de Nietzsche. 
Todavia, as conclusões da interpretação heideggeriana (Nietzsche como extremo afastamento do ser e da diferença, beco sem saída e final da metafísica que só negativa e inconscientemente anuncia uma nova época) deixam-nos perplexos e insatisfeitos. Segundo nós, isto não se conjuga com o problema, aberto, do sentido a atribuir à noção heideggeriana de um pensamento rememorativo (VATTIMO, 1988, p. 85).

Mas ora, se Vattimo não concorda com o posicionamento de Heidegger sobre seu próprio conceito - o qual diz ser An-denken a atitude do pensamento para rememorar o que fora esquecido, o dar-se histórico do ser -, o que ele entende por An-denken?

Che cosa pensiamo, allora, quando ri-memoriamo l'essere? Possiamo pensare l'essere solo come un gewesen, solo come non (più) presente. Il risalimento della storia della metafisica che Heidegger opera sempre di nuovo nei suoi scritti successivi alla svolta ha la struttura del regressus in infinitum, emblematicamente caratteristico della ricostruzione etimologica. Questo risalimento non ci conduce in nessun luogo, se non a ricordarci dell'essere come di quello da cui abbiamo già sempre preso congedo. L'essere si dà qui solo nella forma del Geschick (l'insieme dell'invio) e della Ueberlieferung (la tras-missione). Nei termini di Nietzsche, il pensiero non risale all'origine per appropriarsene; non fa che ripercorrere le vie dell'erranza, che è la solo ricchezza, il solo essere, che ci sia dato (Id., 1998, p. 182-183). ${ }^{6}$

Inequivocamente, Vattimo interpreta a atitude meditante do ser heideggeriana como um abandono deste mesmo ser. Todavia, abandonado propriamente

6 Que coisa pensamos, então, quando rememoramos o ser? Podemos pensar o ser apenas como gewesen, apenas como não (mais) presente. A remontagem da história da metafísica que Heidegger opera sempre novamente nos seus escritos sucessivos à viragem tem a estrutura do regressus in infinitum, emblematicamente característica da reconstrução etimológica. Essa remontagem não nos conduz a lugar algum, senão a nos recordarmos do ser como daquilo de que temos já sempre abandonado. O ser se dá aqui apenas na forma do Geschick (o conjunto do envio) e da Ueberlieferung (a trans-missão). Nos termos de Nietzsche, o pensamento não retoma as origens para apropriar-se dela; não faz senão repercorrer as vias da errância, que é a única riqueza, o único ser, que nos é dado. [Tradução nossa]. 
dito foi o ser durante a história da metafísica, em seu esquecimento - Seinsvergessenheit (esquecimento do ser) como correlato de Seinsvelarssenheit (abandono do ser) (Cf. HEIDEGGER, 1989, p. 110ss).

O conjunto do envio do ser mencionado por Vattimo também atesta contra sua interpretação do conceito. Isto porque o envio não é só passado, mas é presente e, anseia Heidegger, propriamente também futuro, em consonância com o nexo da temporalidade autêntica proposta já em Ser e Tempo. O envio do ser, em seu conjunto, é sua própria escatologia: pensa-se, aqui, em sua unidade originária, e não historiograficamente, como algo passado, ido embora. Na unidade escatológica das épocas do ser, as suas épocas são destinadas a realizar-se quando consumadas finalmente em seu princípio: como bem constatou Vattimo em um texto seu de juventude, Essere, storia e linguaggio in Heidegger (1969), diferentemente de seu pensamento mais maduro, no suceder-se das épocas o ser está sempre por vir (Cf. VATTIMO, 1989, p. 24). ${ }^{7}$

Entendendo o corpus heideggerianum como um todo, percebe-se que também a essência do poetar rememorante é condizente com a temporalidade autêntica apresentada pelo filósofo em Ser e Tempo. Rememorar, por conseguinte, não é uma atitude que busca no passado o seu conteúdo - tendo-se em vista que a própria noção de passado, presente e futuro já decorrem de uma interpretação inautêntica do tempo -, mas na história do ser e em suas épocas, conforme sua unidade escatológica.

Dessarte, como já dito, a memória evoca a necessidade que sempre houve, mas que até então nunca foi consumada: o pensamento atento ao ser. $\mathrm{Na}$ atitude poetante-pensante de rememorar esta necessidade, o apelo do ser passa a ser ouvido, num movimento precisamente contrário ao seu abandono. Considerar, pois, o ser como sempre ausente é uma constatação da história da metafísica, a qual se demorava apenas na reflexão sobre o ente. Aí sim o ser se dá somente na qualidade de ausente. Esquecido e abandonado, dá-se como algo sempre oculto. Neste contexto, sim, o que se pode fazer é "repercorrer as vias da errância da metafísica" (Cf. Id., 1998, p. 182-183). Entretanto, não é esse o fim último que almeja Heidegger. Superar definitivamente a metafísica é pensar o ser ele mesmo em seu desvelar-se, certamente não presentificando-o, porque essencialmente diferente do ente, propriamente acontecente.

7 Diz André Durte, concordando com Vattimo: “O pensamento não calculador, não objetificador do ser, é o pensamento que salta para além das fronteiras da ciência e da filosofia, pois deixa de pensar o ser como fundamento que tenha de ser agarrado e retido de uma vez por todas. $\mathrm{O}$ pensamento rememorativo-meditativo escapa aos procedimentos de presentificação representativa do ser, na medida em que pensa o ser como envio já sempre ocorrido, como já sempre acontecido" (DUARTE, 2010, p. 141). [Nota do pesquisador]. 
Pensando a seu modo, preso à metafísica - embora sempre de modo negativo -, Vattimo crê que An-denken

È ciò che Heidegger stesso si è sforzato di fare, nelle opere successive a Sein und Zeit, nelle quali non elabora più un discorso sistematico, ma si limita a ripercorrere $\mathrm{i}$ grandi momenti della storia della metafisica quali si esprimono nelle grandi sentenze di poeti e pensatori. È un errore considerare questo lavoro di ripercorrimento della storia della metafisica come un semplice lavoro preparatorio, che dovrebbe servire alla costruzione di una ontologia positiva successiva. Il rammemorare come ripercorrimento dei momenti decisivi della storia della metafisica è la forma definitiva del pensiero dell'essere che ci è dato realizzare (Id., 1998, p. 126-127). ${ }^{8}$

A memória, contudo, não é a forma definitiva do pensamento para Heidegger. Ela é somente o modo mais próprio que a humanidade dispõe hoje para lembrar aquilo que cabe pensar. De fato, recordar-se de que precisa pensar algo já é efetivamente pensar este algo, participando parcialmente deste pensamento. Mas o ponto de chegada do pensamento do ser em sua plenitude ainda não ocorreu, mas dele se avizinha o ser humano através da atitude rememorativa, a qual, serenamente, aguarda (Cf. HEIDEGGER, 2000b, p. 20ss). O ser, não como algo que deva ser abandonado como pretende Vattimo, é aquilo que para nós, garante Heidegger, está ainda $a$-se-pensar. E esta necessidade é posta pela poesia pensante.

Memória é a concentração do pensar da lembrança daquilo que, antes de tudo e antes de mais nada, cabe pensar. Esta concentração guarda junto de si e abriga em si o que, sempre e antes de mais nada, permanece e se anuncia como o a-se-pensar em tudo o que anuncia como o vigente e o vigor de ter sido (Id., 2012a, p. 118).

8 É aquilo que Heidegger mesmo se esforçou por fazer, nas obras sucessivas a Sein und Zeit, nas quais não elabora mais um discurso sistemático, mas se limita a repercorrer os grandes momentos da história da metafísica, os quais se exprimem nas grandes sentenças de poetas e pensadores. É um erro considerar este trabalho de repercorrer a história da metafísica como um simples trabalho preparatório, que deva servido à construção de uma ontologia positiva sucessiva. O rememorar como repercorrer os momentos decisivos da história da metafísica é a forma definitiva do pensamento do ser que nos é dado realizar. [Tradução nossa]. 
Tanto não é a forma definitiva de pensamento que, diz o texto $O$ que quer dizer pensar? (1951-52), nós "ainda não pensamos" (Ibid., p. 119), e, consequentemente, que a Pós-Modernidade, ao menos como a entende Vattimo, ainda não pensa, porque o ser ainda não se avizinhou dela, senão como algo ainda a-se-pensar. Contudo, pode-se rememorar a necessidade esquecida de seu pensamento - é isto, pois, o que Hölderlin principiou por fazer, segundo Heidegger. Este rememorar põe a necessidade de se pensar o ser, mas ainda não é seu pensamento propriamente dito. O que merece ser pensado se desvia de nós. Não compete ao homem esforçar-se por pensar o ser, porque este envio depende do ser mesmo.

"Então, só nos resta uma coisa. Só nos resta esperar - esperar até que "o a-se-pensar" se nos anuncie” (Ibid., p. 120). Não seria preciso esperar por coisa alguma se An-denken fosse a forma final do pensamento; bastaria regozijarmo-nos por termos alcançado a plenitude do que quer dizer pensar. Todavia, não é o caso. Ainda é preciso, assegura Heidegger, paciência. Ainda é preciso aguardar que o ser, em seu destino, irrompa como um novo e originário começo da humanidade.

\section{Considerações finais}

O antagônico distanciamento entre Heidegger e sua interpretação por parte de Vattimo, desse modo, aparenta se dar através de uma série de perspectivas ontológicas diametralmente opostas. Em suma, enquanto o pensador da Floresta Negra pretende dirigir o pensamento ao ser e seu sentido, Vattimo procura enfraquecer o pensamento ao aceitar a condição niilista pós-moderna de esquecimento do ser, rememorá-lo apenas como sempre ausente; defende um pensamento sem fundamento, em que não há um apelo à verdade. O ser abandonado por Vattimo é precisamente o ansiado por Heidegger. À distância daquele, este aspira pensar a verdade do ser, ainda impensável; não adere ao nada de ser proporcionado pelo niilismo da era da técnica consumada, mas, pelo contrário, serenamente aguarda um novo e originário começo para a humanidade.

Fato é que, se o pensiero debole de Vattimo é uma constatação do cenário teórico-filosófico pós-moderno, um cenário niilista e, ao menos aparentemente, relativista, Heidegger não pode ser incluído em seu movimento, senão como uma reação a ele. Ante o niilismo, o pensador da Floresta Negra se apresenta apenas como contrário, sempre apenas negativamente, uma vez que sua filosofia pretende ser uma superação do niilismo através de um retorno ao originário. 
Também não pode inserir-se em um contexto relativista, dado que essa liberdade interpretativa proposta por Vattimo - a qual, prima facie, não parece diferente de uma subjetividade elevada à máxima potência - é totalmente contrária ao maior lema fenomenológico, também adotado por Heidegger: às coisas elas mesmas.

Por fim, enquanto a Pós-Modernidade, tal como descrita por Vattimo, pretende ser um novo começo para a humanidade, caminho para uma democratização dos saberes a partir de um desenrijecimento da razão, a via para um efetivo, embora fraco, outro início dos confrontos do pensamento, Heidegger aguarda por um começo ainda outro, mais original e, portanto, mais verdadeiro; um acontecimento-apropriação entre homem e ser que manifeste o que, ainda hoje, é impensável.

ANTISERI, Dario. Le ragione del pensiero debole: domande a Gianni Vattimo. Roma: Borla, 1995.

BLANC, Mafalda Faria. O fundamento em Heidegger: "Vom Wesen des Grundes" - "Der Satz vom Grund": Interpretação-Perspectivação. Lisboa: Instituto Piaget, 1984.

CAPUTO, John D. Being, Ground and Play in Heidegger. Man and World. Pennsylvania: State College, v. 3, n. 1, pp. 26-48, 1970.

CASANOVA. Marco Antônio. Nada a caminho: impessoalidade, niilismo e técnica na obra de Martin Heidegger. Rio de Janeiro: Forense Universitária, 2006.

COUTURAT, Louis. (Org.). Opuscules et fragments inédits de Leibniz. Paris: Félix Alcan, 1903. and the Truth that Prevails". In: CROWELL, Steven; MALPAS, Jeff. (Org.). Transcendental Heidegger. Stanford: Stanford University Press, 2000.

HEIDEGGER, Martin. A questão da técnica. Tradução de Marco Aurélio Werle. Scientiæ Studia. São Paulo: USP, v. 5, n. 3, p. 375-398, 2007.

.Basic Concepts. Tradução de Gary E. Aylesworth. Bloomington; Indianapolis: Indiana University Press, 1993.

.Carta sobre o Humanismo. Tradução de Rubens Eduardo Frias. 2. ed. São Paulo: Centauro, 2005.

.Conferências e Escritos Filosóficos. Tradução de Ernildo Stein. São Paulo: Nova Cultural, 1996. 
manuel Carneiro Leão, Gilvan Fogel e Márcia Sá Cavalcante Schuback. Bragança Paulista: São Francisco; Petrópolis: Vozes, 2012a.

.Introdução à Metafísica. Tradução de Emmanuel Carneiro Leão. Rio de Janeiro: Tempo Brasileiro, 1969.

.Gesamtausgabe. Band 40: Einführung in die Metaphysik. Frankfurt am Main: Vittorio Klostermman, 1983.

.Gesamtausgabe: Band 65: Beiträge zur Philosophie (Vom Ereignis). Vittorio Klostermann: Frankfurt am Main, 1989.

.Marcas do Caminho. Tradução de Enio Paulo Giachini e Ernildo Stein; revisão da tradução de Marco Antonio Casanova. Petrópolis: Vozes 2008.

.Nietzsche: Metafísica e Niilismo. Tradução de Marco Antonio Casanova. Rio de Janeiro: Relume Dumará, 2000a.

.O Princípio do Fundamento. Tradução de Jorge Telles Menezes. Lisboa: Instituto Piaget, 1999.

.Ser e Tempo. Tradução de Fausto Castilho. Petrópolis: Vozes; Campinas: Editora da Unicamp, 2012b.

.Serenidade. Tradução de Maria Madalena Andrade e Olga Santos. Lisboa: Instituto Piaget, 2000b.

HÖLDERLIN, Friedrich. Poesía Completa: edición bilingüe. 5 ed. Barcelona: Ediciones 29, 1995.

PÖGGELER, Otto. A via do pensamento de Martin Heidegger. Tradução de Jorge Telles de Menezes. Lisboa: Instituto Piaget, 2001.

SEVERINO, Emanuele. Heidegger e la metafisica. Milano: Adelphi, 1994.

VATTIMO, Giani. As aventuras da diferença: o que significa pensar depois de Heidegger e Nietzsche. Lisboa: Edições 70, 1988.

.Essere, storia e linguaggio in Heidegger. 2 ed. Genova: Marietti, 1989.

.La fine della Modernità. 2. ed. Milano: Garzanti, 1998.

.ROVATTI, ROVATTI, Pier Aldo. (Org.). Il Pensiero Debole. 2. ed. Milano: Feltrinelli, 2011, p. 10. 